\title{
EFFECT OF LOCATOR ATTACHMENTS WITH DIFFERENT RETENTIVE INSERT MATERIALS ON PERI-IMPLANT TISSUE HEALTH IN MANDIBULAR IMPLANT OVERDENTURE
}

\author{
Alaa M. Elazaly*, Salah A. Hegazy**, Ahmed S. Salem****and Mohamed M. Said****
}

\begin{abstract}
Aim: To compare between nylon and PEEK retentive insert of locator attachments on periimplant tissue health in mandiblar implant overdenture.

Materials and methods: Twelve completely edentulous healthy patients were selected for this study. Every patient received two implants at the canine region bilaterally. According to the type of attachment received, patients were divided into two groups: Group I: overdenture was retained by locator attachment with nylon retentive insert $(n=6)$; Group II: overdenture was retained by locator attachment with PEEK retentive insert $(n=6)$. Evaluation of peri-implant tissue health was done for two implant-retained mandibular overdenture with locator attachment at overdenture insertion, after two weeks, three months and six months using plastic periodontal probe. The categories of peri-implant tissue health evaluation in this study included plaque index, bleeding on probing, and probing depth. The data was analyzed using SPSS and p-value less than 0.05 was considered significant.
\end{abstract}

Results: At base line and 2 weeks, no significant difference in plaque scores was observed between groups. At 3 months and 6 months, PEEK inserts recorded significant higher plaque scores than nylon inserts. At all observation times, no significant difference in bleeding on probing scores was observed between two groups. Nylon inserts recorded significant higher probing depth than PEEK inserts at all observational times.

Conclusion: PEEK insert could provide a successful alternative to nylon insert for locator attachment in implant-retained overdenture. However, long term follow-up is needed due to the significant increase in plaque accumulation for PEEK inserts.

KEYWORDS: Dental implants, overdenture, locator attachment

\footnotetext{
* Postgraduate Student, Department of Prosthodontic, Mansoura University, Egypt

** Professor, Department of Prosthodontic, Mansoura University, Egypt

*** Associate Professor, Department of Oral and Maxillofacial Surgery, Mansoura University, Egypt

**** Lecturer, Department of Prosthodontic, Mansoura University, Egypt
} 


\section{INTRODUCTION}

Mandibular two implant overdentures is considered first choice standard of care for edentulous patients ${ }^{(1)}$. The placement of two implants in the canine region for implant overdenture provides better stability, higher patient satisfaction and greater retention. It also results in increased biting force with the prosthesis ${ }^{(2)}$.

Implant overdentures may use variety of attachment systems which could be solitary or splinted to connect the implant to the denture. Solitary-based attachment are individual abutment such as, ball, magnet, and locator or equator ${ }^{(3)}$. Splinted attachment is bar which splint the implants together. There are many factors for the selection of attachment systems such as the amount of space available, maintenance requirements, load distribution to the mucosa and implant, and the level of retention and resistance desired ${ }^{(4)}$.

The locator attachment is self-aligning with dual retention and is available in different colors with different retention values. They are resilient retentive and durable and have some built-in angulation compensation. In addition, repair and replacement are easy and fast ${ }^{(5)}$. The locator attachments with polyetherketoneketone (PEEK) or nylon insert are now present and have important role on peri-implant tissue health in retained mandibular overdenture ${ }^{(6)}$. Limited research is currently available about the effect of different retentive male insert materials on peri-implant tissue health. Hence, the aim of the current study was to compare between nylon and PEEK retentive male insert of locator attachments on peri-implant tissue health in mandibular implant overdenture.

\section{MATERIALS AND METHODS}

Twelve completely edentulous healthy patients were selected for this study from the out-patient clinic, Prosthodontics Department, Faculty of Dentistry, Mansoura University. All patients informed about all surgical procedures and their role in the follow-up. The study protocol was approved by the ethics committee of Faculty of Dentistry, Mansoura University.

Every patient received a conventional complete denture. To confirm the selected implant site, a duplicate of the mandibular denture was made from clear acrylic and used as a radiographic stent with radio-opaque gutta-purcha markers at the proposed implant position. The denture duplicate was double scanned (Dual scan protocol) using cone beam computed tomography (CBCT). CBCT scan of the patient wearing a stable radiographic guide (mandibular denture) was taken. A mucosal supported stereolithographic surgical guide from 3D printer was constructed and used for implant placement. The implants were placed at the canine area bilaterally and preferably tightened with torque ratchet at $35 \mathrm{Ncm}$, and then healing caps were screwed. Mandibular denture was relieved and relined after 3 weeks for reinsertion. After 3 months of healing, the healing caps were removed, and locator abutments were screwed. Protective disk was placed over the head of each locator abutment, to block out the area immediately surrounding the abutment and, prevent acrylic resin ingress inside underlining tissue and to create a space (Fig. 1). The space created allowed for pivoting of metal denture cap over the insert to provide resiliency. According to the type of attachment, patients were divided into two groups:

Group I: where the mandibular implant overdenture was retained by locator attachment with nylon retentive male insert $(n=6)$.

Group II: where the mandibular implant overdenture was retained by locator attachment with PEEK retentive male insert ( $n=6)$ (Fig.2). 


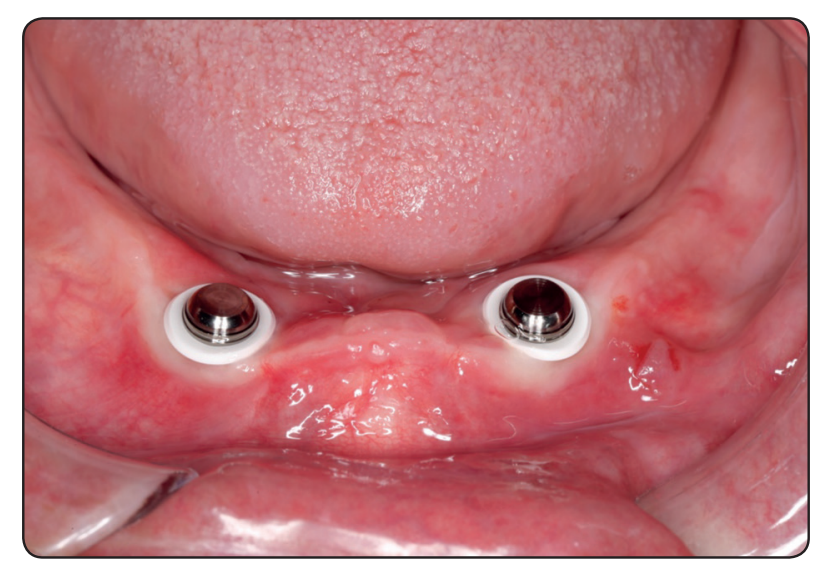

Fig. (1) Protective disk was placed over the head of each locator abutment, to block out the area immediately surrounding the abutment

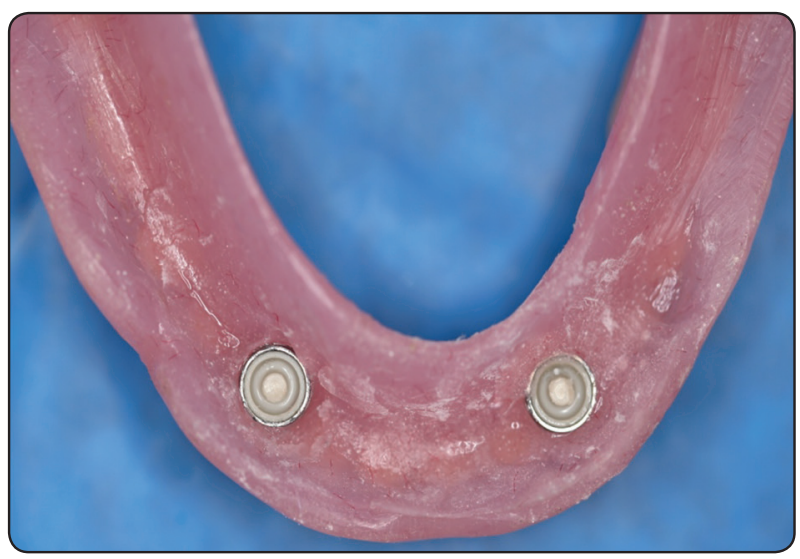

Fig. (2) Mandibular implant overdenture was retained by locator attachment with PEEK retentive male insert

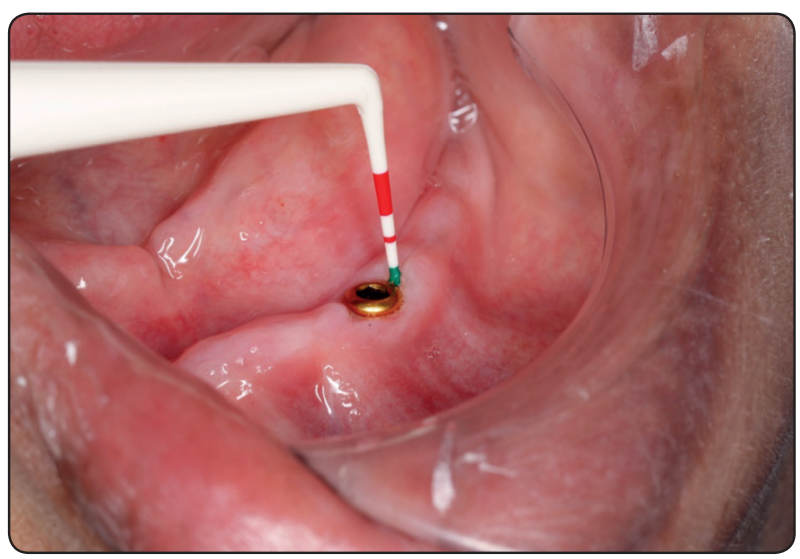

Fig. (3) Evaluation of peri-implant tissue health was done using plastic periodontal probe
Evaluation of peri-implant tissue health was done for two implant-retained mandibular overdenture with locator attachment at overdenture insertion, after two weeks, three months and six months using plastic periodontal probe (Fig. 3). The categories of peri-implant tissue health evaluation in this study included plaque index, bleeding on probing, and peri-implant probing depth ${ }^{(7,8)}$.

\section{Statistical Analysis}

The descriptive statistics of plaque scores, bleeding on probing the scores, and probing depth including mean, standard deviation, median, minimum, and maximum. Shapiro-Wilk test was used to verify the normal distribution of data. The plaque scores, bleeding on probing the scores, and probing depth data were non-parametric and not normally distributed. Mann Whitney test was used to compare plaque scores, bleeding on probing the scores, and probing depth between groups. Freidman test was used to compare plaque scores, bleeding on probing the scores, and probing depth between observation times followed by Wilcoxon signed ranks test for pairwise comparisons. $P$ value is significant if it was less than .05. The data was analyzed using SPSS (statistical package for social science, version 25).

\section{RESULTS}

\section{Plaque scores}

Comparison of plaque scores between groups and observation times is presented in table 1. At base line and 2 weeks, no significant difference in plaque scores was observed between groups. At 3 months and 6 months, PEEK inserts recorded significant higher plaque scores than nylon inserts. There was a significant difference in plaque scores between observation times for nylon and PEEK inserts.

\section{Bleeding on probing scores}

Comparison of bleeding on probing scores between groups and observation times is presented in 
TABLE (1) Comparison of plaque scores between groups and observation times

\begin{tabular}{|c|c|c|c|c|c|c|c|}
\hline & \multicolumn{3}{|c|}{$\begin{array}{c}\text { Group } 1 \\
\text { (Nylon insert) }\end{array}$} & \multicolumn{3}{|c|}{$\begin{array}{c}\text { Group } 2 \\
\text { (PEEK insert) }\end{array}$} & \multirow{2}{*}{$\begin{array}{c}\text { Mann-Whitney } \\
\text { test } \\
\text { (p value) }\end{array}$} \\
\hline & M & Min & Max & M & Min & Max & \\
\hline base line & $.00^{\mathrm{a}}$ & .00 & .00 & $.00^{\mathrm{a}}$ & .00 & .00 & 1.00 \\
\hline 2 weeks & $.00^{\mathrm{a}}$ & .00 & .00 & $.00^{\mathrm{a}}$ & .00 & 1.00 & .317 \\
\hline 3 months & $.00^{\mathrm{a}}$ & .00 & 1.00 & $1.00^{\mathrm{b}}$ & .00 & 1.00 & $.010 *$ \\
\hline 6 months & $.00^{\mathrm{b}}$ & .00 & 1.00 & $1.00^{\mathrm{b}}$ & .00 & 1.00 & $.048^{*}$ \\
\hline Freidman test ( $\mathrm{p}$ value) & & $.014 *$ & & & $.000 *$ & & \\
\hline
\end{tabular}

M; median, min; minimum, max; maximum, * $p$ is significant at 5\% level. Different letters in the same column indicates a significant difference between medians of each 2-observation times (p<.05). The same letters showed no significant difference.

TABLE (2) Comparison of bleeding on probing scores between groups and observation times

\begin{tabular}{|c|c|c|c|c|c|c|c|}
\hline & \multicolumn{3}{|c|}{$\begin{array}{c}\text { Group } 1 \\
\text { (Nylon insert) }\end{array}$} & \multicolumn{3}{|c|}{$\begin{array}{c}\text { Group } 2 \\
\text { (PEEK insert) }\end{array}$} & \multirow{2}{*}{$\begin{array}{c}\text { Mann-Whitney } \\
\text { test } \\
\text { (p value) }\end{array}$} \\
\hline & M & Min & $\operatorname{Max}$ & M & Min & Max & \\
\hline base line & $.00^{\mathrm{a}}$ & .00 & .00 & $.00^{\mathrm{a}}$ & .00 & .00 & 1.00 \\
\hline 2 weeks & $.00^{\mathrm{a}}$ & .00 & .00 & $.00^{\mathrm{a}}$ & .00 & .00 & 1.00 \\
\hline 3 months & $.00^{\mathrm{a}}$ & .00 & 1.00 & $.00^{\mathrm{b}}$ & .00 & 1.00 & .108 \\
\hline 6 months & $.00^{\mathrm{b}}$ & .00 & 1.00 & $.00^{\mathrm{b}}$ & .00 & 1.00 & .732 \\
\hline Freidman test ( $\mathrm{p}$ value) & & $.004 *$ & & & $.001^{*}$ & & \\
\hline
\end{tabular}

M; median, min; minimum, max; maximum, * $p$ is significant at 5\% level. Different letters in the same column indicates a significant difference between medians of each 2-observation times ( $p<.05)$. The same letters showed no significant difference.

Table (3). Comparison of probing depth between groups and observation times

\begin{tabular}{|c|c|c|c|c|c|c|c|}
\hline & \multicolumn{3}{|c|}{$\begin{array}{c}\text { Group } 1 \\
\text { (Nylon insert) }\end{array}$} & \multicolumn{3}{|c|}{$\begin{array}{c}\text { Group } 2 \\
\text { (PEEK insert) }\end{array}$} & \multirow{2}{*}{$\begin{array}{c}\text { Mann-Whitney test } \\
\text { (p value) }\end{array}$} \\
\hline & M & Min & Max & M & Min & Max & \\
\hline base line & $2.00^{\mathrm{a}}$ & 1.00 & 3.00 & $1.00^{\mathrm{a}, \mathrm{c}}$ & .00 & 3.00 & $.010 *$ \\
\hline 2 weeks & $2.00^{\mathrm{a}}$ & 1.00 & 3.00 & $1.50^{\mathrm{a}, \mathrm{b}, \mathrm{c}}$ & .00 & 3.00 & $.017 *$ \\
\hline 3 months & $2.00^{\mathrm{a}}$ & 1.00 & 3.00 & $2.00^{\mathrm{b}}$ & 1.00 & 2.00 & $.047 *$ \\
\hline 6 months & $2.50^{\mathrm{a}}$ & 2.00 & 3.00 & $1.00^{\mathrm{c}}$ & 1.00 & 2.00 & $.000 *$ \\
\hline Freidman test ( $\mathrm{p}$ value) & & .05 & & & $.024 *$ & & \\
\hline
\end{tabular}

M; median, min; minimum, max; maximum, * $p$ is significant at $5 \%$ level. Different letters in the same column indicates a significant difference between medians of each 2-observation times ( $p<.05)$. The same letters showed no significant difference. 
table 2. At all observation times, no significant difference in bleeding on probing scores was observed between groups. There was a significant difference in bleeding on probing scores between observation times for nylon and PEEK inserts.

\section{Probing depth}

Comparison of probing depth between groups and observation times is presented in table 3. At all observation times, nylon inserts recorded significant higher probing depth than PEEK inserts. There was no significant difference in probing depth between observation times for nylon inserts. There was a significant difference in probing depth between observation times for PEEK inserts.

\section{DISCUSSION}

Implant over dentures using the locator show a high implant success rate of over $94.5 \%$ and requires low maintenance as compared to the other solitary type attachments due to its average life. Locator attachment characterized by its low profile, dual retention, allowance for divergence and its self-aligning ability which aids the patient in positioning their prosthesis ${ }^{(9)}$. In this study, CBCT was used in preoperative planning and evaluation of alveolar bone conditions and in stereolithographic surgical stent fabrication. Assessment of peri-implant parameter was done to evaluate peri-implant mucosal conditions around implants to predict long term success of implants.

Modified plaque index at all observation times for group 1 (nylon insert) showed an increase in 3 months period of study and continued in 6 months, while for group 2 (PEEK insert) showed gradual increase from two weeks. There was a significant difference in plaque scores between observation times for nylon and PEEK inserts. For nylon inserts, 6 months recorded significant higher plaque scores compared to base line, 2 weeks and 3 months. For PEEK inserts, 3 months and 6 months showed sig- nificant higher plaque scores than base line and 2 weeks. This may be due to the resiliency of the locator attachment, which allows denture movements and accumulation of food particles and plaque under the denture ${ }^{(10)}$. This may also be attributed to the insufficient oral hygiene in this period resulting from the patient's lack of the ability to perform self-care with a relatively inaccessible cleansing of abutments (11, 12). This might be in agreement with Al-Dharrab (13) who reported that some patients were unable to sustain the same level of oral hygiene and relapses were seen. Frequent recall visits must be scheduled to reinforce and motivate the patient's oral hygiene.

Plaque scores at base line and 2 weeks, there was no significant difference observed between groups. While at 3 months and 6 months, PEEK inserts recorded significant higher plaque scores than nylon inserts. The present PEEK attachments provided a slot in the insert. This slot expands when connecting matrix and patrix, buffering deterioration of the insert surface and diminishing wear of the material (6). This may cause insertion and removal of the denture difficult so that the patients wear denture for long time causing accumulation of plaque more than nylon insert.

The results of this study revealed that at all observation times, no significant difference in bleeding on probing scores were observed between groups. This was because follow-ups of the present study were only for 6 months. Therefore, it is recommended to make a longer follow-up to record if there any difference in bleeding on probing scores between groups. There was a significant difference in bleeding on probing scores between observation times for nylon and PEEK inserts. For nylon inserts, 6 months recorded significant higher bleeding on probing scores compared to base line, 2 weeks and 3 months. For PEEK inserts, the highest bleeding on probing scores were observed with 3 months and 6 months and the lowest scores was observed with base line and 2 weeks. This because there 
is significant plaque accumulation on 6 months on both groups compared baseline and 2 weeks. This increase during the 3 months period may be because oral hygiene of most patients investigated in this study appeared to be insufficient in 3 months observation period. These results were in agreement with Oetterli, et al ${ }^{(14)}$ where a significant increase of the plaque index was observed with time. This may be attributed to plaque accumulation that induce gingivitis which may exhibit various patterns of observable signs and symptoms of inflammation that are localized to the gingiva and initiated by the accumulation of amicrobial biofilm leading to bleeding.

Probing depth at all observation times for group 1 (nylon insert) was not significant. Probing depth at observation times for group 2 (PEEK insert) increased gradually from the base line to the 3 months then decrease in 6 months because at 2 weeks and 3 months. There may be a tissue response leading to increase probing depth and after that in 6 months tissue adaptation occur and probing depth decreased.

The results of this study revealed that nylon inserts recorded significant higher probing depth than PEEK inserts at all observation times. However, it is important to note that there was no significant difference in probing depth between different observation times for nylon inserts. This may be due to increase collar around the implant from the beginning at the baseline. The results of this study showed that the average probing depths was $3 \mathrm{~mm}$ or less in all periods of study. This agreed with Mombelli, et al. ${ }^{(7)}$ who claimed that successful implants generally allow a probe penetration of approximately $3 \mathrm{~mm}$.

Peri-implant tissue health evaluation is very important for the detection of early signs of peri-implant diseases. Experimental and human studies have proved evidence that formation and development of a microbial biofilm is an important etiologic factor in the pathogenesis of peri implantitis and subsequent marginal bone loss. The current study had a few limitations such as the short followup period and the small number of participants. In summarization of this study, it could be that patients treated with an implant supported overdenture need more treatment interventions, treatment time and aftercare maintenance visits.

\section{CONCLUSION}

PEEK insert could provide a successful alternative to nylon insert for locator attachment for implant-retained overdenture. However, other studies with long follow-up time and greater number of patients are required to validate the results of this study.

\section{REFERENCES}

1. Thomason JM. The McGill Consensus Statement on Overdentures. Mandibular 2-implant overdentures as first choice standard of care for edentulous patients. Eur J Prosthodont Restor Dent. 2002 Sep;10(3):95-6.

2. Flanagan D. Bite force and dental implant treatment: a short review. Med Devices (Auckl). 2017 Jun 27;10:141148 .

3. Prasad D K PDA, Buch M. . Selection of attachment systems in fabricating an implant supported overdenture. J Dent Implant. 2014;:4:176-81.

4. Yoda N, Matsudate Y, Abue M, Hong G, Sasaki K. Effect of attachment type on load distribution to implant abutments and the residual ridge in mandibular implantsupported overdentures. J Dent Biomech. 2015 Mar $16 ; 6: 1758736015576009$.

5. Miler AMQP, Correia ARM, Rocha JMC, Campos JCR, da Silva MHGF. Locator $®$ attachment system for implant overdentures: a systematic review. Stomatologija. 2017;19(4):124-129.

6. Choi JW, Yun BH, Jeong CM, Huh JB. Retentive Properties of Two Stud Attachments with Polyetherketoneketone or Nylon Insert in Mandibular Implant Overdentures. Int J Oral Maxillofac Implants. 2018 Sep/Oct;33(5): 1079-1088. 
7. Mombelli A, van Oosten MA, Schurch E Jr, Land NP. The microbiota associated with successful or failing osseointegrated titanium implants. Oral Microbiol Immunol. 1987 Dec;2(4):145-51.

8. Eickholz P, Grotkamp FL, Steveling H, Mühling J, Staehle HJ. Reproducibility of peri-implant probing using a force-controlled probe. Clin Oral Implants Res. 2001 Apr;12(2):153-8.

9. Schneider AL, Kurtzman GM. Restoration of divergent free-standing implants in the maxilla. J Oral Implantol. 2002;28(3):113-6.

10. Elsyad MA, Mahanna FF, Elshahat MA, Elshoukouki AH. Locators versus magnetic attachment effect on periimplant tissue health of immediate loaded two implants retaining a mandibular overdenture: a 1-year randomised trial. J Oral Rehabil. 2016 Apr;43(4):297-305.
11. Chen S, Darby I. Dental implants: maintenance, care and treatment of peri-implant infection. Aust Dent J. 2003 Dec;48(4):212-20.

12. Walter M, Marré B, Eckelt U. Prospective study on titanium bar-retained overdentures: 2-year results. Clin Oral Implants Res. 2000 Aug;11(4):361-9.

13. Al-Dharrab A. Three-year Prospective Evaluation of Immediately Loaded Mandibular Implant Overdentures retained with Locator Attachments. J Contemp Dent Pract. 2017 Sep 1;18(9):842-850.

14. Oetterli M, Kiener P, Mericske-Stern R. A longitudinal study on mandibular implants supporting an overdenture: the influence of retention mechanism and anatomic-prosthetic variables on periimplant parameters. Int J Prosthodont. 2001 Nov-Dec;14(6):536-42. 